\title{
Wpływ turystyki na gospodarki krajów Andyjskiego Wspólnego Rynku (CAN)
}

Kamil Majcher*

\section{Streszczenie}

Celem artykułu jest ocena wpływu sektora turystycznego na gospodarki krajów członkowskich Andyjskiego Wspólnego Rynku - CAN (Kolumbia, Peru, Ekwador, Boliwia) w latach 2011-2019. W pracy wykorzystano metody badawcze w postaci analizy danych empirycznych udostępnionych przez krajowe i międzynarodowe jednostki badawcze, oraz analizy zależności - współczynnik korelacji liniowej Pearsona, współczynnik korelacji rang Spearmana.

Na podstawie przeprowadzonych badań można stwierdzić, że kraje CAN cechują się dynamicznym wzrostem wielkości ruchu turystycznego. Świadczy to o coraz większej atrakcyjności rynków CAN w skali międzynarodowej. Analiza zależności wskazuje jednak na to, iż wyłącznie w Ekwadorze i Boliwii zmiana wolumenu ruchu turystycznego jest silnie skorelowana $\mathrm{z}$ bezpośrednim zatrudnieniem w turystyce i bezpośrednim udziałem w krajowym PKB, przy czym najpopularniejsze destynacje turystyczne w CAN - Peru i Kolumbia nie wykazują silnego skorelowania z wybranymi zmiennymi, co potwierdzają estymowane współczynniki korelacji liniowej Pearsona i korelacji rang Spearmana.

Słowa kluczowe: turystyka, rozwój gospodarczy, zatrudnienie, PKB, Andyjski Wspólny Rynek - CAN

JEL: Z32, L83, O54

* Kamil Majcher, magister, Wyższa Szkoła Bankowa we Wrocławiu, kamil.majcher.wroclaw@, gmail.com, https://orcid.org/0000-0003-2403-5614 


\section{Wstęp}

Podejmując rozważania związane z turystyką, należy w pierwszej kolejności zauważyć wielowymiarowy charakter tego zjawiska. Na dotychczasowy dorobek naukowy w zakresie turystki i jej rozwoju duży wpływ miały nauki humanistyczne, społeczne i przyrodnicze. Można wymienić takie dziedziny naukowe, jak: antropologia, socjologia, geografia, psychologia, polityka, ekonomia czy historia. Dociekania naukowe koncentrowały się także w sferze dyscyplin naukowych i obszarów tematycznych związanych z biznesem, komunikacją, kulturą, hotelarstwem, transportem i handlem detalicznym (Korstanje 2016, s. 32; Manhas i in. 2016, s. 26).

$\mathrm{Z}$ ekonomicznego punktu widzenia turystykę należy rozumieć jako zjawisko o dużym i stale rosnącym znaczeniu gospodarczym i społecznym, rozpoznawanym w krajach na różnym poziomie zaawansowania ekonomicznego. Ten rodzaj aktywności gospodarczej w wielu państwach i regionach o szerokim potencjale rozwoju zyskuje współcześnie na znaczeniu. Turystyka uznawana jest za jedną z głównych opcji rozwoju - w szczególności w krajach rozwijających się (developing countries), ponieważ może pozytywnie stymulować nie tylko rozwój gospodarczy, lecz także rozwój społeczny i kulturowy. Natomiast w krajach rozwiniętych (developed countries) stanowi ważny element konsumpcji i jest swoistym wyznacznikiem nowoczesności i dobrobytu (Alejziak 2011, s. 7).

$\mathrm{Na}$ podstawie literatury można stwierdzić, że korzyści ekonomiczne dla obszarów recepcji turystycznej, a tym samym całego kraju, płynące z rozwoju turystyki w dużej mierze zależą od polityki państwa. Zarówno w ujęciu krótko-, jak i długoterminowym usługi turystyczne stają się źródłem korzyści społeczno-gospodarczych dla sektora turystycznego i pozostałych gałęzi gospodarki związanych z nim w sposób bezpośredni i pośredni (tzw. efekt mnożnikowy w turystyce), dotyczących m.in. wpływu na PKB, wpływów dewizowych, wzrostu zatrudnienia, rewitalizacji kultury, międzynarodowego podejścia kulturowego, rozwoju przedsiębiorczości lokalnej oraz szkolnictwa wyższego i specjalistycznego (Garcia i Lavalle 2012, s. 14; Szopa i Szczerbowski 2013, s. 31-32). Niezwykle istotny efekt mnożnikowy (multiplier effect), który przedstawił i rozwinął w pierwszej połowie XX w. J.M. Keynes (Rusu 2011; Klimiuk 2016), obejmuje w turystyce całość skutków pierwszego wydatku turystycznego, a więc dochodów bezpośrednich, pośrednich oraz indukowanych, powstających w kolejnych fazach oddziaływania w obrębie gospodarki (Guzik, Ostrowska 2013, s. 62).

Badania naukowe $\mathrm{w}$ zakresie gospodarki turystycznej w przekroju terytorialnym poszczególnych krajów świata bądź w ujęciu szerszym, a więc krajowym, pozostają w centrum zainteresowania ekonomistów i badaczy. Najwięcej publikacji akademickich - zarówno w polskiej, jak i zagranicznej literaturze ekonomicznej - poświęcono tematyce rozwoju turystyki i jej wpływu na PKB oraz potencjału turystycznego krajów, obszarów, regionów recepcji turystycznej (Roca 
2003; Coromoto 2007; Klimek 2008; Wites 2009; Brida i in. 2011; Comporek 2012; Jasiński, Suchta 2013; Zurub i in. 2015; Caro i in. 2015). Kwerenda polskiej literatury naukowej wskazuje na to, iż badania w obrębie turystyki Andyjskiego Wspólnego Rynku - CAN pozostają w zasadzie pomijane, a ogólny zasób publikacji akademickich dotyczący ugrupowania jest niezwykle skąpy (Majcher 2019, 2020, 2021). Wagę i zasadność podjętej w artykule tematyki i przedmiotu dociekań podkreśla również fakt, iż uwarunkowania przemian w światowej turystyce związane są obecnie w głównej mierze z procesami globalizacyjnymi i integracyjnymi (Zdon-Korzeniowska i Rachwal 2011, s. 116).

Celem artykułu jest ocena wpływu sektora turystycznego na gospodarki krajów członkowskich Andyjskiego Wspólnego Rynku - CAN (Kolumbia, Peru, Ekwador, Boliwia) w latach 2011-2019. Hipotezy badawcze zweryfikowane w pracy brzmią następująco:

- zmiany w wolumenie napływających turystów nie pozostają skorelowane ze zmianami w turystycznym rynku pracy i bezpośrednim udziale turystyki w PKB krajów CAN;

- zmiany w wolumenie napływających turystów pozostają silnie skorelowane ze zmianami w turystycznym rynku pracy i bezpośrednim udziale turystyki w PKB krajów CAN;

- zmiany w wolumenie napływających turystów pozostają słabo skorelowane ze zmianami w turystycznym rynku pracy i bezpośrednim udziale turystyki w PKB krajów CAN.

W niniejszej pracy zastosowano metodę badawczą w postaci analizy dostępnych danych empirycznych (analiza struktury zbiorowości i dynamiki zjawisk) oraz analizy zależności. Materiał statystyczny pobrany został z bazy danych krajowych i międzynarodowych jednostek badawczych. Z kolei strukturę artykułu podporządkowano realizacji założonego celu i weryfikacji hipotez badawczych. Punktem wyjścia artykułu jest część pierwsza, w której zaprezentowano materiał i metodę badań. W części drugiej przedstawiono wielkość i dynamikę ruchu turystycznego z podziałem na kraje oraz w CAN ogółem. W ostatnim fragmencie zaprezentowano wyniki analizy zależności korelacyjnej.

\section{Materiał i metoda badań}

Zdefiniowany cel i hipotezy zdeterminowały decyzję o wyborze źródeł oraz metod badawczych w pracy. Podstawę przeprowadzonych badań empirycznych stanowią materiały statystyczne pobrane $\mathrm{z}$ baz danych krajowych i międzynarodowych jednostek badawczych za okres 2011-2019. Tylko w przypadku analizy wielkości ruchu turystycznego poszerzono zakres czasowy do $2020 \mathrm{r}$. ze względu na dostępność aktualnych danych. Do najważniejszych należy zaliczyć materiały 
publikowane przez Międzynarodową Organizację Turystyki Narodów Zjednoczonych (UNWTO), a także cykliczne publikacje Ministerstwa ds. Turystyki Ekwadoru (MINTUR), Ministerstwa ds. Handlu Zagranicznego i Turystyki Peru (MINCETUR), Ministerstwa ds. Handlu, Przemysłu i Turystyki Kolumbii (MINCIT), Narodowego Instytutu Statystyki w Boliwii (INE), Narodowego Instytutu Statystyki i Informatyki w Peru (INEI). W opracowaniu wykorzystano także polski i zagraniczny dorobek naukowy z zakresu poruszanej problematyki, w główniej mierze czasopiśmienniczy.

$\mathrm{W}$ artykule zastosowano metodę badawczą $\mathrm{w}$ postaci analizy dostępnych danych empirycznych (analiza struktury zbiorowości i dynamiki zjawisk) oraz analizy współzależności zjawisk (zależność korelacyjna). Zebrany i zweryfikowany materiał statystyczny umożliwił wykorzystanie narzędzia w postaci współczynnika korelacji liniowej Pearsona $\left(\mathrm{r}_{x y}\right)$. W kolejnym etapie prac miernik ten pozwolił na ocenę zależności pomiędzy przyrostami wielkości ruchu turystycznego w krajach członkowskich CAN a przyrostami PKB bezpośrednio generowanymi przez sektor turystyczny tych państw, a także przyrostami zatrudnienia w przemyśle turystycznym. Współczynnik korelacji liniowej Pearsona pozostaje najczęściej używanym typem współczynnika korelacji i przyjmuje następującą formułę (Wilkowski 2009, s. 191-192):

$$
\mathrm{r}_{x y}=\mathrm{r}_{y x}=\frac{\operatorname{cov}(x, y)}{\mathrm{s}(x) \mathrm{s}(y)}
$$

gdzie: $\operatorname{cov}(x, y)=\frac{1}{n} \sum_{i=1}^{n}\left(x_{i}-\bar{x}\right)\left(y_{i}-\bar{y}\right)-$ kowariancja badanych cech $(x, y), \mathrm{s}(x)$ - odchylenie standardowe cechy $x, \mathrm{~s}(y)$ - odchylenie standardowe cechy $y$

Współczynnik korelacji liniowej Pearsona jest miarą siły (stopnia) liniowego związku pomiędzy dwiema losowymi zmiennymi $x$ i $y$, i przyjmuje wartości $\mathrm{z}$ przedziału $-1 \leq \mathrm{r}_{x y} \leq 1$, przy czym, jeśli $\mathrm{r}_{x y}=0$ nie występuje związek liniowy pomiędzy zmiennymi, natomiast jeśli $\mathrm{r}_{x y}=1$ lub $\mathrm{r}_{x y}=-1$ występuje funkcyjny związek liniowy pomiędzy zmiennymi (odpowiednio: wprost proporcjonalny, odwrotnie proporcjonalny) (Stefanów 2011, s. 248). Estymacja współczynnika korelacji liniowej Pearsona $\left(\mathrm{r}_{x y}\right)$ umożliwia określenie współczynnika determinacji $\left(\mathrm{r}^{2}{ }_{x y}\right)$, który stanowi jego kwadrat i zwyczajowo prezentowany jest $\mathrm{w}$ ujęciu procentowym.

Kolejnym narzędziem wykorzystanym w pracy jest wskaźnik korelacji rang Spearmana $\left(\mathrm{r}_{\mathrm{s}}\right)$, który przyjmuje następującą postać (Wiśniewski 2014, s. 175):

$$
\mathrm{r}_{\mathrm{s}}=1-\frac{6 \sum_{\mathrm{i}=1}^{\mathrm{n}} \mathrm{d}_{\mathrm{i}}^{2}}{\mathrm{n} \cdot\left(\mathrm{n}^{2}-1\right)}
$$

gdzie: $\mathrm{d}_{\mathrm{i}}{ }_{\mathrm{i}}$ - kwadrat różnicy pomiędzy rangami odpowiadających sobie wartości $x$ i $y, \mathrm{n}$ - liczba obserwacji. 
Przy estymacji współczynnika korelacji rang Spearmana wykorzystywane są rangi, które stanowią numery nadane zarówno wartościom cechy $x$, jak i $y$ w kolejności malejącej bądź rosnącej. Omawiany współczynnik podobnie jak współczynnik korelacji liniowej Pearsona przyjmuje wartości z przedziału $-1 \leq \mathrm{r}_{\mathrm{s}} \leq 1$ (Stefanów 2011, s. 256).

Zastosowane mierniki pozwalają na empiryczną weryfikację postawionych w publikacji hipotez badawczych. Z punktu widzenia poruszanej materii warto także wspomnieć o pewnych ograniczeniach - sezonowości w branży turystycznej, która nie jest wykrywana przez współczynniki korelacji.

\section{Wolumen ruchu turystycznego w CAN}

Kraje członkowskie CAN stanowią atrakcyjne rynki recepcyjne, które rokrocznie przyciągają dużą liczbę turystów zagranicznych, co potwierdzają dane zamieszczone na Wykresie 1. Ustalono, że w 2011 r. łączna wielkość ruchu turystycznego w CAN wynosiła 6,4 mln osób. W kolejnych latach (2011-2018) nastąpiło wyraźne zdynamizowanie napływu turystów zagranicznych do krajów wspólnoty. Natomiast w $2018 \mathrm{r}$. kraje CAN jako destynację turystyczną wybrało $12,0 \mathrm{mln}$ osób. W tym samym czasie niniejsze osiąi stanowiły odpowiednio $24,0 \%$ i $32,7 \%$ wszystkich turystów odwiedzających kontynent południowoamerykański (UNWTO 2021). Jest to z całą pewnością sytuacja korzystna z punktu widzenia gospodarki turystycznej krajów CAN, w szczególności Peru (4,4 mln osób) i Kolumbii (4,0 mln osób). Należy podkreślić, że w 2019 r. Kolumbia wraz z Boliwią (w przypadku Peru - poziom bez zmian) odnotowały najwyższy wzrost liczby odwiedzających turystów (odpowiednio o 5,0\% i 9,1\%). Z kolei istotny spadek wielkości dotyczył tylko Ekwadoru (o 16,0\%). Taka sytuacja może wynikać w pewnym stopniu z niepokojów społecznych w tym kraju, których eskalacja w 2019 r. doprowadziła do wprowadzenia stanu wyjątkowego.

Poważnym problemem dla indywidualnych gospodarek narodowych CAN, jak i całej gospodarki światowej, stała się epidemia koronawirusa COVID-19, której początek przypada na pierwszy kwartał 2020 r. Decydenci w większości krajów świata, również w CAN, zdecydowali się na częściowe lub całkowite zamknięcie gospodarki - lockdown. Przykładowo w Peru tego rodzaju rozwiązanie zostało przyjęte 16 marca 2020 r. (Castro 2020, s. 1). Działania rządzących - niedostępna baza noclegowa, baza gastronomiczna, placówki o charakterze kulturowym, np. muzea, problem z dostępnością lotniczą - wpływały na poszczególne gałęzie gospodarki, w tym na turystykę. $Z$ tego powodu w 2020 r. łączna liczba turystów odwiedzających kraje CAN drastycznie spadła (mianowicie o 75,6\% w stosunku do roku poprzedniego) i oscylowała na poziomie 2,9 mln osób. Jednak najwięcej przyjazdów zagranicznych zarejestrowano w Kolumbii (1,2 mln osób), następnie w Peru ( 0,9 mln osób), Ekwadorze ( 0,5 mln osób) i Boliwii (0,3 mln osób). 
Wykres 1. Wielkość ruchu turystycznego (w mln osób) w Peru, Kolumbii, Boliwii, Ekwadorze, CAN ogółem w latach 2011-2020 oraz indeks dynamiki zmian (w \%, $100=$ rok poprzedni) w latach 2012-2020
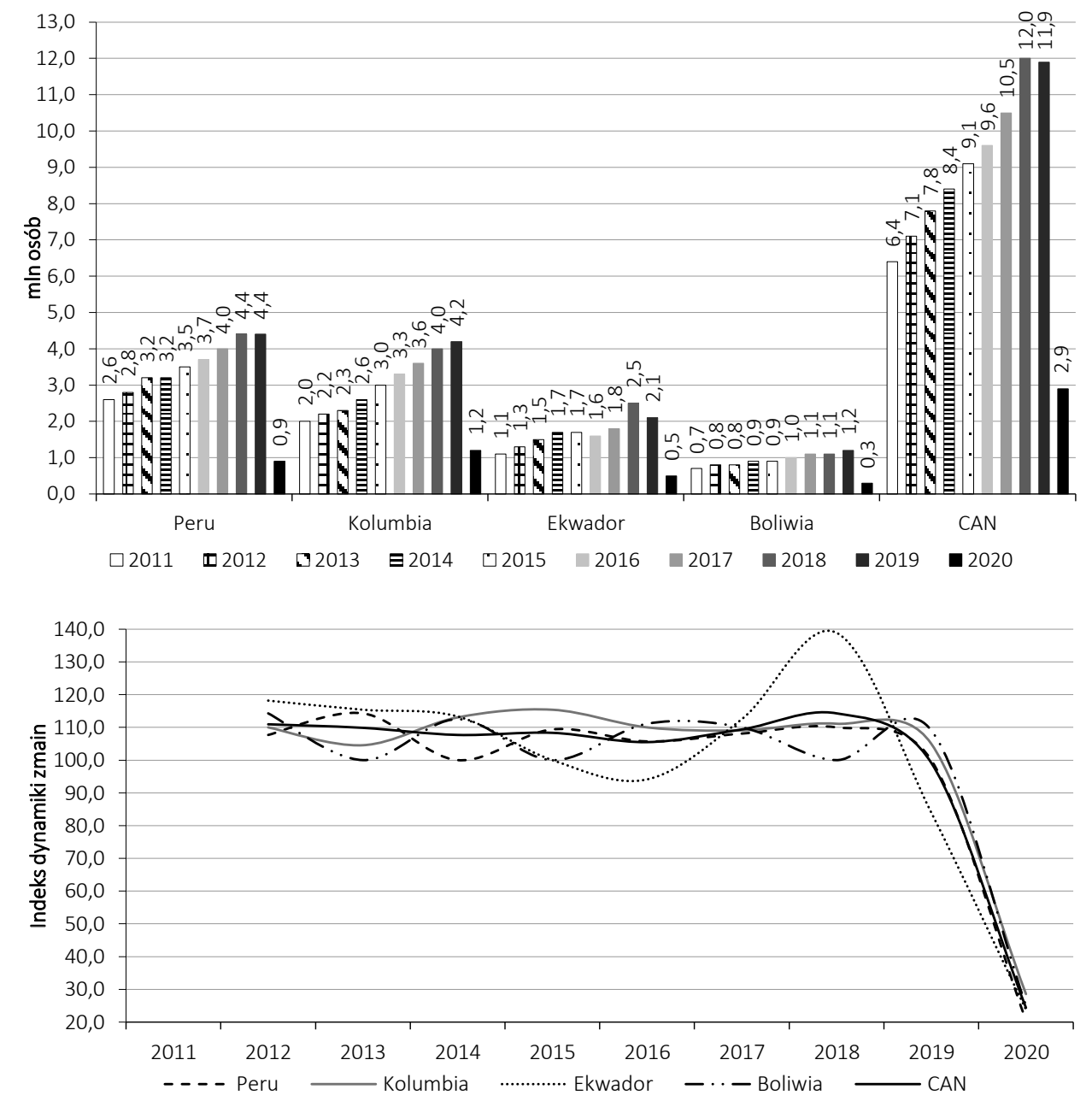

Źródło: opracowanie własne na podstawie UNWTO (2021).

Na podkreślenie zasługuje fakt, iż kraje członkowskie CAN wciąż wyraźnie odbiegają od głównych światowych rynków recepcyjnych pod względem cyklicznego wolumenu turystów zagranicznych. Dane przedstawione w Tabeli 1 pokazują, w jaki sposób w wybranych latach kształtowała się pozycja krajów należących do CAN na tle trzech głównych światowych destynacji turystycznych. Wciąż największą popularnością mogą pochwalić się Francja i ościenna Hiszpania (pozycja druga w latach 2015, 2017, 2019). Silną pozycję posiadają ponadto Stany Zjednoczone, które permanentnie zajmują miejsce w pierwszej trójce najczęściej 
odwiedzanych rynków na świecie. Nie można także pominąć roli Chin, które w 2011 r. były trzecim co do wielkości rynkiem destynacji turystycznej w ujęciu globalnym.

Spośród krajów subregionu Peru zajmowało najwyższą coroczną pozycję $\mathrm{w}$ światowym rankingu, oscylując $\mathrm{w}$ granicach 50 miejsca. Peru to kraj słynący z doskonale zachowanej sztuki rdzennych ludów, które przed wiekami zamieszkiwały ten teren. W związku z tym dużą popularnością cieszą się pozostałości unikatowej kultury Inków, które można zobaczyć w regionie Cuzco. W 2019 r. turyści zagraniczni przybyli do stolicy regionu - Cuzco w liczbie 1,07 mln osób. Ponadto w promieniu kilkudziesięciu kilometrów od niego znajdują się pozostałe inkaskie miasta - historyczne sanktuarium Machu Picchu, które odwiedziło blisko 1,22 mln osób oraz Ollantaytambo i Pisac, które stały się celem podróży turystycznej dla odpowiednio 604 tys. osób i 428 tys. osób (INEI 2021; MINCETUR 2021). Wprowadzone przez władze lokalne ograniczenia ilościowe (m.in. limity w sprzedaży dziennych biletów wstępu) i czasowe (bilety czasowe) w dostępie do Machu Picchu skutecznie usprawniają kontrolę nad liczbą odwiedzających turystów.

Tabela 1. Trzy główne destynacje turystyczne na świecie oraz pozycja krajów członkowskich CAN w światowym rankingu (lata: 2011, 2013, 2015, 2017, 2019)

\begin{tabular}{|c|c|c|c|c|}
\hline $\mathbf{2 0 1 1}$ & $\mathbf{2 0 1 3}$ & $\mathbf{2 0 1 5}$ & $\mathbf{2 0 1 7}$ & $\mathbf{2 0 1 9}$ \\
\hline Pozycja/Kraj & Pozycja/Kraj & Pozycja/Kraj & Pozycja/Kraj & Pozycja/Kraj \\
\hline 1/Francja & 1/Francja & 1/Francja & 1/Francja & 1/Francja \\
\hline 2/St. Zjedn. & 2/St. Zjedn. & 2/St. Zjedn. & 2/Hiszpania & 2/Hiszpania \\
\hline 3/Chiny & 3/Hiszpania & 3/Hiszpania & 3/St. Zjedn. & 3/St. Zjedn. \\
\hline 55/Peru & 50/Peru & 51/Peru & 54/Peru & 51/Peru \\
\hline 61/Kolumbia & 59/Kolumbia & 53/Kolumbia & 57/Kolumbia & 53/Kolumbia \\
\hline 70/Ekwador & 67/Ekwador & 62/Ekwador & 72/Ekwador & 67/Ekwador \\
\hline 74/Boliwia & 74/Boliwia & 70/Boliwia & 78/Boliwia & 76/Boliwia \\
\hline
\end{tabular}

Objaśnienia: St. Zjedn. - Stany Zjednoczone.

Źródło: opracowanie własne na podstawie UNWTO (2021).

W analizowanym okresie zauważa się wzrost znaczenia Kolumbii, która w 2011 r. plasowała się na pozycji 61, natomiast w 2019 r. zajęła miejsce 53. Główną destynacją podróży okazał się dystrykt stołeczny kraju - Bogota, którą odwiedziło blisko 1,26 mln osób, następnie dystrykt Bolivar - 530 tys. osób - z główną atrakcją, jaką stanowi jego stolica - Kartagena. Z kolei Ekwador i Boliwia zajęły niższe pozycje, mianowicie 67 i 76 miejsce (odpowiednio wzrost o trzy i spadek o dwie pozycje w stosunku do 2011 r.).

Według ekwadorskiego Ministerstwa ds. Turystyki - MINTUR (2021) turyści zagraniczni najchętniej odwiedzali stolicę kraju - Quito w prowincji Pichincha. W 2019 r. do tej aglomeracji przybyło ich ponad 680 tys. Wśród cennych walorów turystycznych miasta z pewnością należy wymienić mnogość 
zabytków architektury kolonialnej oraz topografię terenu - położenie na wysokości ok. 3000 m n.p.m. Drugim najczęściej eksplorowanym miastem w tym kraju był Tulcán zlokalizowany przy granicy lądowej z Kolumbią w prowincji Carchi - ponad 580 tys. osób z zewnątrz. Na szczególne zainteresowanie mogła także liczyć największa aglomeracja w kraju - Guayaquil w prowincji Guayas, z liczbą turystów zagranicznych na poziomie ponad 480 tys. osób. Podobna sytuacja występuje w Boliwii, gdzie najwięcej przyjezdnych zarejestrowano w miastach takich jak La Paz - 330 tys. osób i Santa Cruz - 304 tys. osób (INE 2020, s. 11).

\section{Wpływ turystyki na wybrane zmienne ekonomiczne w CAN}

Z punktu widzenia podejmowanej problematyki ważnymi zagadnieniami stają się rola i znaczenie sektora turystycznego w zmiennej ekonomicznej - PKB. Sposób pomiaru rozmiarów aktywności rynku odgrywa istotną rolę w ekonomii, bowiem na nich opierają się decyzje wyboru kierunków polityki gospodarczej dokonywanej przez rząd (Łopatka 2015, s. 46).

$\mathrm{Z}$ danych zaprezentowanych w Tabeli 2 jednoznacznie wynika, że w badanym okresie najwyższy bezpośredni udział procentowy turystyki w krajowym PKB odnotowano w Peru. Wskazują na to coroczne peruwiańskie osiągi sektora turystycznego - średni udział w dochodzie narodowym na poziomie 3,63\% oraz wzrost udziału procentowego w 2019 r. o 0,42 pkt proc. w stosunku do roku bazowego. W analogicznym czasie również w ujęciu bezwzględnym nastąpił wyraźny wzrost udziału o 3,4 mld USD (60,7\%).

Tabela 2. Bezpośredni udział turystyki (w \%, w mld USD) w PKB krajów CAN

\begin{tabular}{|l|r|r|r|r|r|r|r|r|r|r|r|}
\hline \multirow{2}{*}{ Rok } & PE & CO & \multicolumn{1}{|c|}{ EC } & BO & CAN & PE & CO & EC & BO & CAN \\
\cline { 2 - 11 } & \multicolumn{9}{|c|}{ \% PKB } & \multicolumn{5}{|c|}{ mId USD } \\
\hline 2011 & 3,28 & 1,77 & 1,76 & 2,72 & 2,23 & 5,6 & 5,9 & 1,4 & 0,7 & 13,6 \\
\hline 2012 & 3,37 & 1,73 & 1,85 & 2,88 & 2,26 & 6,5 & 6,4 & 1,6 & 0,8 & 15,3 \\
\hline 2013 & 3,57 & 1,75 & 1,90 & 2,44 & 2,32 & 7,2 & 6,7 & 1,8 & 0,7 & 16,4 \\
\hline 2014 & 3,68 & 1,76 & 2,02 & 2,73 & 2,38 & 7,4 & 6,7 & 2,0 & 0,9 & 17,0 \\
\hline 2015 & 3,84 & 2,04 & 2,19 & 2,87 & 2,66 & 7,3 & 6,0 & 2,2 & 0,9 & 16,4 \\
\hline 2016 & 3,81 & 1,97 & 2,18 & 2,79 & 2,63 & 7,4 & 5,6 & 2,2 & 0,9 & 16,1 \\
\hline 2017 & 3,70 & 1,90 & 2,29 & 2,78 & 2,58 & 7,9 & 6,0 & 2,4 & 1,0 & 17,3 \\
\hline 2018 & 3,71 & 1,92 & 2,76 & 2,74 & 2,67 & 8,5 & 6,5 & 2,9 & 1,1 & 19,0 \\
\hline 2019 & 3,70 & 1,92 & 2,74 & 2,71 & 2,67 & 9,0 & 6,6 & 3,0 & 1,2 & 19,8 \\
\hline Średnia & 3,63 & 1,86 & 2,19 & 2,74 & 2,49 & 7,4 & 6,4 & 2,2 & 0,9 & 16,8 \\
\hline $\begin{array}{l}\text { Zmiana w 2019 r. } \\
(100=2011)\end{array}$ & - & - & - & - & - & 160,7 & 111,9 & 214,3 & 171,4 & 145,6 \\
\hline
\end{tabular}

Źródło: opracowanie własne na podstawie Knoema (2021). 
Spośród państw członkowskich CAN Boliwia stanowiła drugi (po Peru) kraj z najwyższym średnim udziałem sektora turystycznego w PKB. Choć został on ustalony na poziomie $2,74 \%$, nie zauważa się dynamicznego wzrostu, lecz przeciwnie - spadek o 0,1 pkt proc. w stosunku do 2011 r. W przypadku Ekwadoru i Kolumbii zauważa się mniejsze znaczenie turystyki w strukturze krajowego PKB - średni udział odpowiednio na poziomie 2,19\% i 1,86\%. Za istotne należy jednak uznać zachodzące tendencje w obu gospodarkach. Obserwuje się zdynamizowanie wzrostu udziału sektora turystyki w 2019 r. w stosunku do bazowego zarówno w Ekwadorze na poziomie 0,98 pkt proc., jak i w Kolumbii, choć w mniejszym stopniu, ponieważ na poziomie 0,15 pkt proc.

Kolejny ważny aspekt stanowi turystyczny rynek pracy w krajach CAN. $\mathrm{Z}$ danych zaprezentowanych w Tabeli 3 wynika, iż liczba osób zatrudnionych $\mathrm{w}$ przemyśle turystycznym $\mathrm{w}$ państwach członkowskich CAN systematycznie wzrasta. Jednak mieszkańcy omawianych państw pracują w branżach bezpośrednio lub pośrednio powiązanych z sektorem turystycznym. Poprzez zaangażowanie bezpośrednie rozumie się przede wszystkim zatrudnienie w przedsiębiorstwach turystycznych i rekreacyjnych, które jako jednostki organizacyjne prowadzą działalność gospodarczą polegającą na odpłatnym świadczeniu usług turystycznych i rekreacyjnych (Alejziak 2014, s. 122). Tak więc są to usługi związane z bazą noclegową (np. hotelarstwo) i gastronomiczną, a ponadto aktywności wynikające z organizacji turystyki i pośrednictwa turystycznego. W całym okresie średnia liczba osób pracujących w turystyce, w sposób bezpośredni zaangażowanych w obsługę turystów, kształtowała się na najwyższym poziomie w Kolumbii. Warto podkreślić, że w latach 2017-2019 w omawianym kraju liczba ta przekroczyła 500,0 tys. osób.

Tabela 3. Średni poziom zatrudnienia (w tys. osób) w sektorze turystycznym w krajach CAN

\begin{tabular}{|c|c|c|c|c|r|}
\hline \multirow{2}{*}{ Lata } & Peru & Kolumbia & Ekwador & Boliwia & CAN \\
\cline { 2 - 5 } & \multicolumn{7}{|c|}{ w tys. osób } \\
\hline \multicolumn{7}{|c|}{ Bezpośrednie zatrudnienie } \\
\hline $2011-2013$ & 334,0 & 418,0 & 115,0 & 101,0 & 968,0 \\
\hline $2014-2016$ & 382,0 & 492,0 & 144,0 & 111,0 & 1129,0 \\
\hline $2017-2019$ & 397,0 & 506,0 & 189,0 & 114,0 & 1206,0 \\
\hline \multicolumn{7}{|c|}{ Całkowite zatrudnienie (bezpośrednie i pośrednie) } \\
\hline $2011-2013$ & 1125,0 & 1046,0 & 274,0 & 259,0 & 2704,0 \\
\hline $2014-2016$ & 1289,0 & 1204,0 & 342,0 & 279,0 & 3114,0 \\
\hline $2017-2019$ & 1306,0 & 1272,0 & 414,0 & 295,0 & 3287,0 \\
\hline
\end{tabular}

Źródło: opracowanie własne na podstawie Knoema (2021).

Szersze spojrzenie na turystykę CAN umożliwia analiza całkowitego zatrudnienia w tej gałęzi gospodarki. Włącza się tutaj również takie branże, jak komunikacja, budownictwo, kultura i rozrywka, a nawet rolnictwo. W latach 2017-2019 
w sposób pośredni i bezpośredni w krajach wspólnoty zatrudniono 3287,0 tys. osób. Najwięcej, bo aż 1306,0 tys. osób, zaangażowanych było na peruwiańskim rynku pracy. Jednak niewiele mniej, bo 1272,0 tys., pracowało w Kolumbii. Tendencja wzrostowa obserwowana na wszystkich rynkach pracy CAN świadczy o umocnieniu się roli i znaczenia turystyki w tych gospodarkach.

Uzyskane wartości współczynników korelacji liniowej Pearsona i korelacji rang Spearmana zaprezentowano w Tabeli 4 . Na podstawie pierwszego z mierników można stwierdzić, że w badanym czasie w ugrupowaniu CAN nie zachodzi liniowy związek pomiędzy przyrostem wielkości ruchu turystycznego a przyrostem wielkości zatrudnienia (pośredniego i bezpośredniego), jak również przyrostem bezpośredniego udziału w PKB omawianych krajów $\left(\mathrm{r}_{x y}<0,500\right)$. Na podkreślenie zasługuje jednak uzyskany wynik współczynnika korelacji rang Spearmana wskazujący na istotną zależność pomiędzy zmianą ruchu turystycznego w CAN a zmianą w skumulowanym PKB tych państw $\left(\mathrm{r}_{\mathrm{s}}=0,613\right)$.

Tabela 4. Współczynnik korelacji liniowej Pearsona oraz korelacji rang Spearmana pomiędzy zmianą $\mathrm{w}$ wielkości ruchu turystycznego $(\Delta \mathrm{T})$ a zmianą w bezpośrednim zatrudnieniu w turystyce $\left(\Delta \mathrm{Z}_{\mathrm{B}}\right)$, całkowitym zatrudnieniu $\mathrm{w}$ turystyce $\left(\Delta \mathrm{Z}_{\mathrm{C}}\right)$ i udziałem bezpośrednim turystyki w PKB krajów członkowskich $\mathrm{CAN}\left(\triangle \mathrm{PKB}_{\mathrm{B}}\right)$

\begin{tabular}{|c|l|c|c|c|}
\hline Państwo & Rodzaj korelacji & $\boldsymbol{x}_{\mathbf{i}}=\Delta \mathbf{Z}_{\mathbf{B}} ; \boldsymbol{y}_{\mathbf{i}}=\Delta \mathrm{T}$ & $\boldsymbol{x}_{\mathbf{i}}=\Delta \mathbf{Z}_{\mathbf{C}} ; \boldsymbol{y}_{\mathbf{i}}=\Delta \mathbf{T}$ & $\boldsymbol{x}_{\mathbf{i}}=\Delta \mathbf{P K B}_{\mathbf{B}} ; \boldsymbol{y}_{\mathbf{i}}=\boldsymbol{\Delta} \mathbf{T}$ \\
\hline \multirow{2}{*}{ CAN } & Pearsona & 0,268 & 0,134 & 0,394 \\
\cline { 2 - 5 } & Spearmana & 0,404 & $-0,023$ & $\mathbf{0 , 6 1 3}$ \\
\hline \multirow{2}{*}{ Kolumbia } & Pearsona & 0,349 & 0,464 & $-0,385$ \\
\cline { 2 - 5 } & Spearmana & 0,250 & 0,273 & $-0,184$ \\
\hline \multirow{2}{*}{ Peru } & Pearsona & 0,285 & 0,063 & 0,204 \\
\cline { 2 - 5 } & Spearmana & 0,369 & 0,077 & 0,315 \\
\hline \multirow{2}{*}{ Boliwia } & Pearsona & 0,882 & 0,778 & 0,866 \\
\cline { 2 - 5 } & Spearmana & 0,845 & 0,738 & 0,916 \\
\cline { 2 - 5 } & Pearsona & $\mathbf{0 , 5 6 2}$ & 0,420 & $\mathbf{0 , 5 6 5}$ \\
\hline
\end{tabular}

Źródło: obliczenia własne.

Ekwador to jedyny członek ugrupowania, w którym zachodzi dodatnia zależność pomiędzy badanymi zmiennymi. Wzrost napływu turystów na rynek ekwadorski ma wpływ na generowane miejsca pracy - zarówno te bezpośrednio (najwyższa zależność liniowa $-\mathrm{r}_{x y}=0,882$ ) - jak i pośrednio i bezpośrednio związane $\mathrm{z}$ sektorem turystycznym $\left(\mathrm{r}_{x y}=0,778\right)$. Wartości współczynnika determinacji, które zobrazowano na Wykresie 2, wyraźnie informują o tym, iż w pierwszym przypadku w 77,79\% omawiana zmienna wpłynęła na zmiany $\mathrm{w}$ zatrudnieniu bezpośrednim. Z kolei w drugim przypadku współczynnik determinacji pozwala 
stwierdzić, że w ten sposób można wyjaśnić $60,53 \%$ zmienności zatrudnienia pośredniego w turystyce Ekwadoru. Również w przypadku zmiany wolumenu turystów napływających a zmianą bezpośredniego udziału turystyki w ekwadorskim PKB zachodzi silna dodatnia zależność $\left(\mathrm{r}_{x y}=0,866\right)$. Istotne znaczenie ma także fakt, że opierając się na indeksie determinacji, ta zmienność może zostać wyjaśniona aż w 75,00\% przez zmiany w cyklicznym ruchu turystycznym na omawianym rynku recepcyjnym. Zbliżone wielkości otrzymano także w wyniku estymacji mierników korelacji rang Spearmana. Szczególnie wysoką wartość otrzymano w odniesieniu do dochodu bezpośredniego, która była bliska $1\left(\mathrm{r}_{\mathrm{s}}=0,916\right)$.

Wykres 2. Indeksy determinacji (w \%)
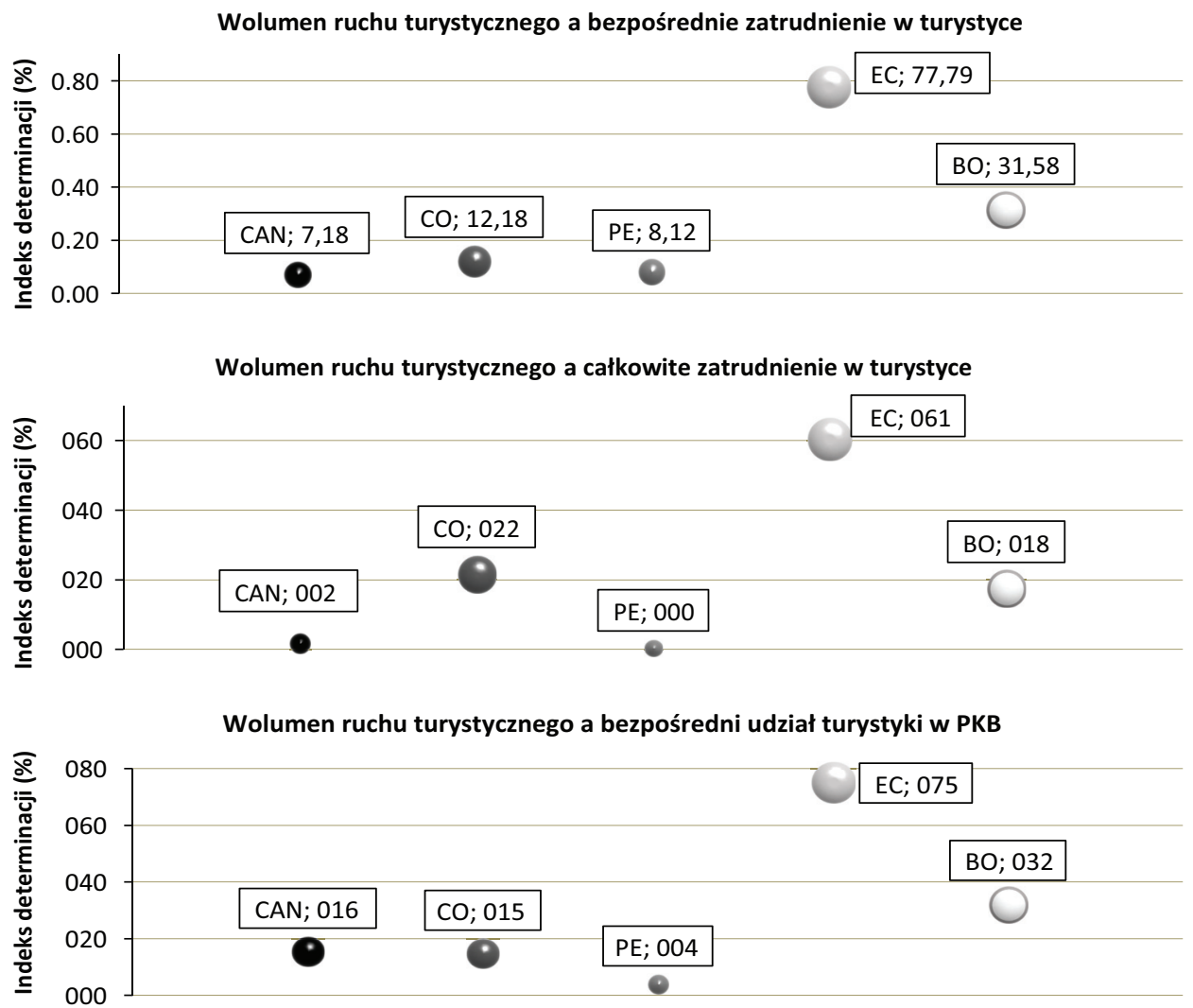

Źródło: opracowanie własne na podstawie Tabeli 4.

Również w Boliwii wzrost napływu turystów korzystnie wpływa na turystyczny rynek pracy, jednak tylko w odniesieniu do miejsc pracy bezpośrednio powiązanych z turystyką. W tym przypadku estymowane mierniki korelacji liniowej Pearsona i korelacji rang Spearmana wskazują na znaczną i dodatnią zależność $\left(\mathrm{r}_{x y}=0,562 ; \mathrm{r}_{\mathrm{s}}=0,577\right)$. Bazując na indeksie determinacji, zmienność 
ta może zostać wyjaśniona w 31,58\% przez zmiany w wielkości napływających turystów. Z kolei w przypadku zatrudnienia całkowitego, dla którego mierniki zależności $<0,500$, zmienność tę można wyjaśnić w zaledwie 17,64\%. Niemniej w przypadku zmiany w udziale bezpośrednim w PKB uzyskano dodatnią zależność, choć o mniejszym nasileniu niż w przypadku tej uzyskanej w gospodarce Ekwadoru $\left(\mathrm{r}_{x y}=0,565 ; \mathrm{r}_{\mathrm{s}}=0,636\right)$.

Odmiennie przedstawia się sytuacja w najpopularniejszych destynacjach turystycznych ugrupowania - Peru i Kolumbii. Wyniki obliczeń świadczą o bardzo słabym wpływie cyklicznych zmian wolumenu turystów na zatrudnienie w turystyce omawianych państw, co potwierdzają estymowane mierniki zależności $\left(\mathrm{r}_{x y}<0,500 ; \mathrm{r}_{\mathrm{s}}<500\right)$. Mając na uwadze indeks determinacji, można stwierdzić, iż tylko w 12,18\% (Kolumbia) i 8,12\% (Peru) zmienność w bezpośrednim zatrudnieniu może zostać uzasadniona zmianą $\mathrm{w}$ ruchu turystycznym na obu rynkach. W Peru wzrost ruchu turystycznego w słabym stopniu wpływa na zmiany w bezpośrednim udziale turystyki w PKB tego kraju $\left(\mathrm{r}_{x y}=0,204 ; \mathrm{r}_{\mathrm{s}}=0,315\right)$. $\mathrm{Z}$ kolei indeks determinacji kształtuje się na niskim poziomie $4,16 \%$. Niniejsze wyniki są dosyć zaskakujące i mogą one wskazywać na silny wpływ pozostałych czynników związanych z polityką gospodarczą kraju. Z kolei w przypadku Kolumbii zauważa się słabą zależność ujemną, a indeks determinacji na poziomie $14,82 \%$ wskazuje na to, że w takim stopniu zmiana PKB może zostać wyjaśniona przez zmianę wolumenu ruchu turystycznego. Przyrost ruchu turystycznego nie oddziałuje zatem w sposób pozytywny na omawianą wielkość ekonomiczną, co pozostaje zjawiskiem niepokojącym.

\section{Podsumowanie}

Badanie przeprowadzone na przykładzie Kolumbii, Peru, Ekwadoru, Boliwii, a więc krajów integrujących się w ramach CAN, pozwala na wysunięcie kilku syntetycznych wniosków oraz spostrzeżeń. Wybór przedmiotu badań wydaje się nieoczywisty ze względu na fakt, iż nie są to główne międzynarodowe kierunki wypoczynku turystycznego. W niniejszej pracy analiza gospodarki turystycznej omawianych państw nie została sprowadzona wyłącznie do określenia zachodzących tendencji w wielkości ruchu turystycznego, turystycznego rynku pracy oraz bezpośredniego udziału turystyki w budowie dochodu narodowego (PKB), lecz także do ustalenia zależności korelacyjnej.

W badanych krajach uwidacznia się rozwój gałęzi turystki poprzez dynamiczny wzrost miejsc pracy zarówno bezpośrednio, jak i pośrednio powiązanych $\mathrm{z}$ branżą. Jest to ogólnie stwierdzenie, jednak kryje się pod nim zdynamizowanie wielu branż i dziedzin życia gospodarczego. Jednocześnie przeprowadzona 
analiza zależności wyraźnie wskazuje na silny wpływ zmiennej w postaci ruchu turystycznego na zatrudnienie oraz PKB w dwóch krajach - Ekwadorze i Boliwii ( $w$ tym przypadku z wyłączeniem zatrudnienia całkowitego). Natomiast w głównych rynkach recepcyjnych wspólnoty - Kolumbii i Peru - zmiany w wielkości ruchu turystycznego nie są silnie skorelowane z generowanymi miejscami pracy. Nie mają także przełożenia na zmiany w bezpośrednim udziale turystyki w kolumbijskim i peruwiańskim PKB.

Więcej wiedzy na temat gospodarki turystycznej krajów CAN dostarczy badanie w postaci analizy porównawczej indeksów funkcji turystycznej oraz infrastruktury turystycznej, która jest podstawą rozwoju funkcji turystycznej regionów.

\section{Bibliografia}

Alejziak B. (2014), Kwalifikacje i kompetencje pracowników turystyki. Próba diagnozy turystycznego rynku pracy, „Folia Turistica”, 32.

Alejziak W. (2011), Tourist activity: International and domestic diversification and the problem of social exclusion, „Tourism”, 21(1-2). https://doi. org/10.2478/v10106-011-0001-9

Brida J.G., Monterubbianesi P.D., Aguirre Z.S. (2011), Impactos del turismo sobre el crecimiento económico y el desarrollo. El caso de los principales destinos turísticos de Colombia, „Revista de Turismo y Patrimonio Cultural”, 9(2). https://doi.org/10.25145/j.pasos.2011.09.026

Caro González F.J. et al. (2015), Turismo, desarrollo sostenible y percepción de los stakeholders. Un estudio de caso en República Dominicana, „Revista de Economia del Caribe", 15.

Castro J.V. (2020), Crónica de la economía peruana en tiempos de pandemia, Documento de Trabajo, Departamento de Economia - Pontificia Universidad Católica del Perú, 495.

Comporek M. (2012), Ustugi turystyczne a kształtowanie rozwoju zrównoważonego i logistyki produktu - studium przypadku gminy Byczyna, „Acta Universitatis Lodziensis. Folia Oeconomica", 272.

Coromoto Morillo M.M. (2007), Análisis del turismo receptivovenezolano, „Contaduría y administración", 222.

Garcia A.V., Lavalle N. (2012), Algunas concideraciones sobre la actividad turistica, „Notas en Turismo y Economia”, 4.

Guzik H., Ostrowska B. (2013), Ekonomiczne aspekty gospodarowania przestrzenia turystyczna, ,Zeszyty Naukowe Uniwersytetu Ekonomicznego w Krakowie", 913. 
INE (2020), Boletin Estadistico-Actividad de Turismo 2019, https://www.ine.gob. bo/index.php/publicaciones/boletin-estadistico-actividad-de-turismo-2019/ (data dostępu: 20.07.2021).

INEI (2021), Turismo, https://www.inei.gob.pe/estadisticas/indice-tematico/economia/ (data dostępu: 20.07.2021).

Jasiński J., Suchta J. (2013), Turystyka jako funkcja rozwoju matych miast województwa warmińsko-mazurskiego, „Acta Universitatis Lodziensis. Folia Geographica Socio-Oeconomica", 15.

Klimek K. (2008), Turystyka na obszarach górskich na przykładzie szwajcarskiego kantonu Valais, ,Zeszyty Naukowe Uniwersytetu Ekonomicznego w Krakowie", 788.

Klimiuk Z. (2016), Ewolucja tradycyjnych koncepcji handlu zagranicznego $w$ teorii ekonomii, ,Zeszyty Naukowe PWSZ w Płocku. Nauki Ekonomiczne" nr 24.

Knoema (2021), Data. Tourism, https://knoema.com/atlas/topics/Tourism (data dostępu: 20.07.2021).

Korstanje M.E. (2016), La Trans-disciplinariedad en los Estudios Turisticos, „Turismo, Desarrollo y Buen Vivir: Revista de Investigación de la Ciencia Turistica-RICIT", 10.

Łopatka A. (2015), Ekonomia dobrobytu. Rachunki narodowe w kontekście pomiaru dobrobytu, „Współczesne problemy ekonomiczne”, 11. https://doi. org/10.18276/wpe.2015.11-04

Majcher K. (2019), Przewaga komparatywna krajów Andyjskiego Wspólnego Rynku (CAN) w międzynarodowym handlu towarami z Mercosur, „Ekonomia Międzynarodowa”, 27. https://doi.org/10.18778/2082-4440.27.01

Majcher K. (2020), Konkurencyjność Andyjskiego Wspólnego Rynku w handlu zagranicznym kawa i jej substytutami, „Ekonomia Międzynarodowa”, 32. https://doi.org/10.18778/2082-4440.32.03

Majcher K. (2021), Poludniowoamerykańska regionalna integracja gospodarcza - przypadek Andyjskiego Wspólnego Rynku (CAN), „Ameryka Lacińska”, 1(111). https://doi.org/10.7311/20811152.2021.111.02

Manhas P.S., Manrai L.A., Manrai A.K. (2016), Role of tourist destination development in building its brand image: A conceptual model, „Journal of Economics, Finance and Administrative Science", 21. https://doi.org/10.1016/j. jefas.2016.01.001

MINCETUR (2021), Datos Turismo, http://datosturismo.mincetur.gob.pe/appdatosTurismo/Content2.html (data dostępu: 20.07.2021).

MINCIT (2021), Flujos Turisticos, https://www.citur.gov.co/estadisticas\#gsc. tab $=0$ (data dostępu: 20.07.2021). 
MINTUR (2021), Llegadas y Salidas Internacionales en Ecuador, https://servicios.turismo.gob.ec/index.php/turismo-cifras/2018-09-19-17-01-51/movimientos-internacionales (data dostępu: 20.07.2021).

Roca M.A. (2003), La continentalización de la isla de San Andrés, Colombia: Panyas, raizales y turismo, 1953-2003, Documentos de Trabajo Sobre Economía Regional u Urbana, Banco de la Republica Cartagena de Indias, 37.

Rusu S. (2011), Tourism multiplier effect, „Journal of Economics and Business Research", 1.

Stefanów P. (2011), Ograniczenia stosowania wspótczynnika korelacji liniowej Pearsona, [w:] Chodyński A. (red.), Przedsiębiorcze aspekty rozwoju organizacji i biznesu, Oficyna Wydawnicza AFM, Kraków.

Szopa R., Szczerbowski M. (2013), Turystyka czynnikiem przemian ekonomicznych, [w:] Nowak S. (red.), Ekonomiczno-organizacyjne problemy działalności turystycznej w regionach, Wydawnictwo AWF, Katowice.

UNWTO (2021), UNWTO Tourism Dashboard, https://www.unwto.org/unwto-tourism-dashboard (data dostępu: 20.07.2021).

Wilkowski A. (2009), O współczynniku korelacji, „Prace Naukowe Uniwersytetu Ekonomicznego we Wrocławiu. Ekonometria”, 26.

Wiśniewski J.W. (2014), Dylematy stosowania współczynnika korelacji Spearma$n a$, ,Studia Ekonomiczne. Uniwersytet Ekonomiczny w Katowicach”, 181.

Wites T. (2009), Rola turystyki w gospodarce Brunei, [w:] Marak J., Wyrzykowski J. (red.), Rola turystyki w gospodarce regionu, vol. 2. Ustugi turystyczne jako podstawa gospodarki turystycznej, Wyższa Szkoła Handlowa, Wrocław.

Zdon-Korzeniowska M., Rachwal T. (2011), Turystyka w warunkach globalnego kryzysu gospodarczego, „Prace Komisji Geografii Przemysłu Polskiego Towarzystwa Geograficznego", 18. https://doi.org/10.24917/20801653.18.10

Zurub H., Ionescu A., Constantin V.D. (2015), Measuring the Economic Impact of Tourism in European Emerging Markets, „Procedia Economics and Finance”, 32. https://doi.org/10.1016/S2212-5671(15)01369-6

\section{Summary}

The influence of tourism on the economy of the Andean Community Countries (CAN)

The aim of the article is to assess the influence of tourism on the economy of the member countries of the Andean Community - CAN (Colombia, Peru, Ecuador, Bolivia) in the years between 2011-2019. The study was conducted using the following methods: the analysis of empirical data provided by national and international research units; the Pearson's linear correlation coefficient and the 
Spearman's rank correlation coefficient. Based on the study, it can be stated that CAN countries are characterized by a dynamic increase in tourist traffic volumes. This demonstrates improved attractiveness of the CAN markets internationally. However, the correlation's analysis conducted in the article confirmed that only in Ecuador and Bolivia the change in the volume of tourist traffic is strongly correlated with direct employment in a tourism sector and a direct share of tourism in the national GDP.

Keywords: tourism, economic development, employment, GDP, the Andean Community - CAN 